\title{
Adenosine $\mathbf{A} 1$ receptor activation attenuates lung ischemia- reperfusion injury
}

\author{
Lucas G. Fernandez, MD, DSc, Ashish K. Sharma, MBBS, Damien J. LaPar, MD, MSc, Irving \\ L. Kron, MD, and Victor E. Laubach, PhD \\ Department of Surgery, University of Virginia Health System, Charlottesville, Virginia, USA
}

\begin{abstract}
Objectives-Ischemia-reperfusion injury significantly contributes to morbidity and mortality in lung transplant patients. Currently no therapeutic agents are clinically available to prevent ischemia-reperfusion injury, and treatment strategies are limited to maintaining oxygenation and lung function. Adenosine can modulate inflammatory activity and injury via binding to various adenosine receptors, but the role of adenosine $A_{1}$ receptor in ischemia-reperfusion injury and inflammation is not well understood. This study tests the hypothesis that selective, exogenous activation of $A_{1}$ receptor is anti-inflammatory and attenuates lung ischemia-reperfusion injury.
\end{abstract}

Methods-Wild-type and $\mathrm{A}_{1}$ receptor knockout mice underwent 1 hour left lung ischemia and 2 hours reperfusion using an in vivo hilar-clamp model. An $\mathrm{A}_{1}$ receptor agonist, CCPA, was administered 5 minutes before ischemia. After reperfusion, lung function was evaluated by measuring airway resistance, pulmonary compliance and pulmonary artery pressure. Wet/dry weight ratio was used to assess edema. Myeloperoxidase and cytokine levels in bronchoalveolar lavage fluid were measured to determine neutrophil infiltration and inflammation.

Results-In wild-type animals, CCPA significantly improved lung function and attenuated edema, cytokine expression and myeloperoxidase levels compared to vehicle-treated mice after ischemia-reperfusion. Lung ischemia-reperfusion injury was similar between $\mathrm{A}_{1}$ receptor knockout and wild-type mice, but CCPA had no effects in $\mathrm{A}_{1}$ receptor knockout mice. In vitro treatment of neutrophils with CCPA significantly reduced chemotaxis.

Conclusions-Exogenous $\mathrm{A}_{1}$ receptor activation improves lung function and decreases inflammation, edema and neutrophil chemotaxis after ischemia-reperfusion. These results suggest a potential therapeutic application for $\mathrm{A}_{1}$ receptor agonists for the prevention of lung ischemiareperfusion injury after transplantation.

\section{INTRODUCTION}

Ischemia reperfusion (IR) injury and its more severe form, primary graft dysfunction, leads to significant morbidity and mortality after lung transplantation with mortality rates approaching $40 \%$. Ischemia is unavoidable during transplantation and the subsequent effect of reperfusion results in significant cellular damage, oxidative stress, innate immune

\footnotetext{
(C) 2013 The American Association For Thoracic Surgery. Published by Mosby, Inc. All rights reserved.

Corresponding author: Victor E. Laubach, PhD, Department of Surgery, University of Virginia Health System, P.O. Box 801359, Charlottesville, VA 22908, Phone: 434-924-2927, Fax: 434-924-1218, laubach@virginia.edu.

All authors declare that they have no conflict of interests.

Publisher's Disclaimer: This is a PDF file of an unedited manuscript that has been accepted for publication. As a service to our customers we are providing this early version of the manuscript. The manuscript will undergo copyediting, typesetting, and review of the resulting proof before it is published in its final citable form. Please note that during the production process errors may be discovered which could affect the content, and all legal disclaimers that apply to the journal pertain.
} 
responses and lung inflammation. ${ }^{1,2}$ During organ inflammation and IR injury such as after transplantation, adenosine is a retaliatory metabolite released from many cell sources and serves largely as a protective agent with anti-inflammatory effects. Adenosine mediates its effects through binding of four different $G$ protein-coupled receptors: $A_{1} R, A_{2 A} R, A_{2 B} R$ and $A_{3} R$, and adenosine receptor signalling typically entails second messenger pathways such as the cAMP-dependent PKA pathway or the phospholipase C pathway.

All four adenosine receptors are expressed in lungs of mice ${ }^{3}$ and humans. ${ }^{4}$ Studies from our laboratory suggest that activation of $A_{1} R$ or $A_{3} R$, via selective agonists, offers protection from lung IR injury in an isolated rabbit lung model. ${ }^{5}$ We have also demonstrated potent anti-inflammatory effects of $\mathrm{A}_{2 \mathrm{~A}} \mathrm{R}$ activation in both a mouse lung IR model ${ }^{6}$ and a porcine lung transplant model. ${ }^{7}$ On the other hand, our studies suggest a proinflammatory role for the $A_{2 B} R$ in the setting of lung IR. ${ }^{8}$ However, the role of $A_{1} R$ in lung IR injury remains controversial and not well understood. $A_{1} R$ is expressed largely on endothelial, epithelial and inflammatory cells and signals through $\mathrm{G}_{\mathrm{i} / \mathrm{o}}$ proteins, and its effects include inhibition of adenylyl cyclase, activation of $\mathrm{K}^{+}$channels, inhibition of $\mathrm{N}$-, $\mathrm{P}$ - and Q-type $\mathrm{Ca}^{+}$channels, and activation of phospholipase $C \beta .{ }^{9}$ Earlier studies reported that $A_{1} R$ antagonism attenuates lung inflammation after IR. ${ }^{10}$ However, more recent studies, including our own, suggest that $\mathrm{A}_{1} \mathrm{R}$ activation has protective effects in several models of inflammatory lung injury. ${ }^{5,11,12}$ Using $\mathrm{A}_{1} \mathrm{R}$ knockout mice and a specific pharmacological $\mathrm{A}_{1} \mathrm{R}$ agonist, the present study tests the hypothesis that specific $A_{1} R$ activation is anti-inflammatory and provides significant protection from lung IR injury.

\section{METHODS}

\section{Animals and Study Design}

Adult male C57BL/6 wild-type (WT) mice (Jackson Laboratories, Bar Harbor, ME) and congenic $A_{1} R$ knockout $\left(A_{1} R-/-\right)$ mice of 8-12 weeks of age were utilized. The $A_{1} R-/-$ mice ${ }^{13}$ were a gift of Dr. Jurgen Schnermann (Institute of Pharmacology and Toxicology, University of Tübingen, Germany). Mice underwent either sham or IR surgery ( $n=6$ mice/ group). Animal were randomly allocated to the various control and experimental groups. Animals were treated with either vehicle (0.1\% DMSO in saline) or 2-chloro-N6cyclopentyladenosine (CCPA, Sigma, St. Louis, MO) via intravenous injection 5 minutes prior to ischemia. CCPA is a highly selective and potent $\mathrm{A}_{1} \mathrm{R}$ agonist (affinity Ki values are 0.4 and $3900 \mathrm{nM}$ for rat $\mathrm{A}_{1} \mathrm{R}$ and $\mathrm{A}_{2 \mathrm{~A}} \mathrm{R}$ respectively), and CCPA is nearly 10,000-fold more selective for $A_{1} R$ than $A_{2 A} R .{ }^{14}$ All animal procedures and protocols used in this study were approved by the Institutional Animal Care and Use Committee at the University of Virginia and conformed to NIH guidelines (Guide for the Care and Use of Laboratory Animals).

\section{Lung IR Model}

Mice underwent 1 hour of left lung ischemia and 2 hours of reperfusion (IR) using an established in vivo hilar-clamp model. ${ }^{6,8}$ Sham animals underwent anaesthesia, left thoracotomy (without hilar clamp) and 2 hours of reperfusion. Analgesic was administered to all animals after surgery.

\section{Measurement of Lung Function}

After reperfusion, pulmonary function was evaluated using an isolated, buffer-perfused lung system (Hugo Sachs Electronik, March-Huggstetten, Germany) as previously described by our laboratory. ${ }^{8}$ After a 5-minute equilibration period, data regarding pulmonary arterial pressure, pulmonary compliance and airway resistance were recorded for an additional 5 minutes using the PULMODYN data acquisition system (Hugo Sachs Elektronik). 


\section{Bronchoalveolar Lavage (BAL)}

After lung function was measured, left lungs were lavaged with $0.4 \mathrm{ml}$ saline. The BAL fluid was then centrifuged $(1,500 \mathrm{rpm}$ for $8 \mathrm{~min})$ and stored at $-80^{\circ} \mathrm{C}$.

\section{Lung Weight/Dry Weight}

Using separate groups of animals ( $n=6 /$ group), the left lung was excised after the reperfusion period, blotted dry, immediately weighed and desiccated until a stable dry weight was reached. The lung wet/dry weight ratio was calculated as a measure of lung edema.

\section{Analysis of Cytokines and Myeloperoxidase (MPO)}

Cytokines were measured in BAL fluid using a mouse Bio-plex ${ }^{\mathrm{TM}}$ cytokine assay (Bio-Rad Laboratories, Hercules, CA) as reported previously. ${ }^{6,8}$ MPO levels were measured in BAL fluid using a mouse MPO ELISA kit (Hycult biotech, Uden, The Netherlands).

Myeloperoxidase is abundant in the azurophilic granules of polymorphonuclear neutrophils and was used as an indicator of neutrophil activation and infiltration into alveolar airspaces.

\section{Chemotaxis Assay}

In vitro migration was assessed in bone marrow-derived murine neutrophils using a commercially available kit $\left(\mathrm{QCM}^{\mathrm{TM}} 5 \mu \mathrm{m}\right.$ Chemotaxis Cell Migration Assay, Millipore). In brief, bone marrow cells were harvested from mouse femurs and tibias by flushing with $10 \mathrm{ml}$ of phosphate buffered saline (PBS) containing $10 \%$ fetal bovine serum (FBS). The suspended cells were centrifuged at $500 \mathrm{~g}$ for 10 minutes. After red blood cells lysis for 2 minutes at room temperature, cells were washed, counted and resuspended in RPMI buffer. Neutrophil isolation was then performed using a commercially available Anti-Ly-6G mouse Microbead kit (Miltenyi Biotech, Bergisch Gladbach, Germany) following the manufacturer's instructions. Neutrophils were resuspended at $2 \times 10^{6}$ cells $/ \mathrm{ml}$ in RPMI buffer with $0.5 \%$ FBS, and $250 \mu 1$ of the cell suspension was incubated in a $5 \mu \mathrm{m}$ insert, with or without $\mathrm{A}_{1} \mathrm{R}$ agonist CCPA $(10 \mathrm{ng} / \mathrm{ml})$, for 30 minutes at $37^{\circ} \mathrm{C}$. $500 \mu \mathrm{l}$ of serum-free medium was then added to the lower chamber, with or without chemoattractant (10\% FBS), and the plate was incubated for 4 hours at $37^{\circ} \mathrm{C}$ in a $\mathrm{CO}_{2}$ incubator. After the incubation period, the upper chamber was removed and the insert was incubated in $400 \mu$ of cell stain for 20 minutes at room temperature. Non-migratory cells were removed from the interior of the insert with a cotton swap and the insert was transferred to a new well containing $200 \mu$ of extraction buffer for 15 minutes. Colorimetric measurement of the reaction was performed at $570 \mathrm{~nm}$ in a plate reader (quant, Bio-Tec, Winooski, VT). Two independent in vitro experiments were performed.

\section{Statistical Analysis}

Results were analyzed by two-way analysis of variance (ANOVA) to determine if significant differences existed between the groups. Comparisons between two groups were analyzed using unpaired Student $t$-test. Data is expressed as mean $\pm \mathrm{SD}$, and a $P$ value of $<0.05$ was considered significant.

\section{RESULTS}

\section{$A_{1} R$ Activation Improves Lung Function After IR}

To measure the effects of exogenous $\mathrm{A}_{1} \mathrm{R}$ activation on pulmonary function after IR, WT and $\mathrm{A}_{1} \mathrm{R}-/-$ mice underwent lung IR following pretreatment with vehicle $(0.1 \% \mathrm{DMSO})$ or CCPA $\left(\mathrm{A}_{1} \mathrm{R}\right.$ agonist, $0.1,1$ and $2 \mathrm{mg} / \mathrm{kg}$ ), and lung function was assessed after 2 hours of reperfusion. IR in vehicle-treated mice significantly increased pulmonary artery pressure and airway resistance and significantly decreased pulmonary compliance (Figure 1). Treatment 
of WT mice with 1 or $2 \mathrm{mg} / \mathrm{kg}$ CCPA resulted in significantly decreased pulmonary artery pressure and airway resistance and significantly increased pulmonary compliance after IR. Lung function in $\mathrm{A}_{1} \mathrm{R}-/-$ mice after IR was similarly impaired as in WT mice after IR; however, CCPA had no protective effects in $A_{1} R-/-$ mice after IR (Figure 1). This demonstrates the specificity of the agonist for $A_{1} R$. No significant differences in lung function were found between WT and $\mathrm{A}_{1} \mathrm{R}-/-$ sham mice (data not shown), and thus only data from WT sham mice are reported in subsequent experiments.

\section{Activation of $A_{1} R$ Reduces Lung Edema After IR}

To evaluate the effects of exogenous $A_{1} R$ activation on lung edema after IR, lung wet/dry weight was measured in mice pretreated with vehicle or CCPA $(0.1,1$ and $2 \mathrm{mg} / \mathrm{kg})$. WT mice had a significantly higher wet/dry weight after IR compared to sham (Figure 2), which was significantly decreased by CCPA (all doses). Lung wet/dry weight after IR was also elevated in $\mathrm{A}_{1} \mathrm{R}-/-$ mice, similar to WT mice after IR (Figure 2).

\section{$A_{1} R$ Activation Attenuates Pro-Inflammatory Cytokine Expression After IR}

To measure the lung inflammatory response after IR, levels of pro-inflammatory cytokines and chemokines were measured in BAL fluid of mice pretreated with vehicle or CCPA $(0.1$, 1 and $2 \mathrm{mg} / \mathrm{kg}$ ). IR in vehicle-treated WT mice resulted in significantly increased levels of IL-6, CXCL1, CCL2 and TNF-a compared to sham mice (Figure 3). Treatment with $2 \mathrm{mg}$ / kg CCPA significantly reduced levels of IL-6, CXCL1 and CCL2 compared to WT mice after IR. TNF-a was also reduced by CCPA, but this did not reach statistical significance $(P=0.069)$. Similar to lung function and wet/dry weight, $\mathrm{A}_{1} \mathrm{R}-/-$ mice after IR had elevated levels of cytokines comparable to WT mice after IR (Figure 3).

\section{Activation of $\mathbf{A}_{\mathbf{1}} \mathbf{R}$ Reduces MPO Levels After IR}

MPO was measured in BAL fluid as an indication of neutrophil activation and infiltration into alveolar airspaces. Vehicle-treated WT mice after IR had significantly elevated MPO levels compared to sham (Figure 4). Treatment with $1 \mathrm{or} 2 \mathrm{mg} / \mathrm{kg}$ CCPA significantly reduced MPO levels after IR to levels similar to sham. $\mathrm{A}_{1} \mathrm{R}-/-$ mice had elevated MPO levels after IR comparable to WT mice (Figure 4).

\section{$A_{1} R$ Agonist Impairs Neutrophil Chemotaxis}

To evaluate a possible direct effect of $A_{1} R$ activation on neutrophil migration, in vitro neutrophil chemotaxis was evaluated using the Boyden chamber method as described in the methods. Bone marrow-derived neutrophils exposed to $10 \%$ FBS as a chemoattractant demonstrated significant chemotaxis (Figure 5). Incubation of neutrophils with CCPA (10ng/ml, 30 minutes before stimulation) significantly attenuated chemotaxis (Figure 5).

\section{DISCUSSION}

Studies on the effects of $A_{1} R$ activation in IR have been controversial. There is evidence for an anti-inflammatory role for $\mathrm{A}_{1} \mathrm{R}$ in lung ${ }^{5}$, liver ${ }^{15}$, kidney ${ }^{16}$, heart ${ }^{17}$, intestine ${ }^{18}$ and skeletal muscle. ${ }^{19}$ However, other studies have suggested that $A_{1} R$ antagonism has beneficial effects in lung and heart IR models. ${ }^{10,20}$ In the current study, we used an in vivo hilar clamp model in WT and $\mathrm{A}_{1} \mathrm{R}-1-$ mice to clarify a protective role of exogenous activation of $A_{1} R$ in lung IR injury. Our results demonstrate the anti-inflammatory effects of CCPA, a potent and selective $A_{1} R$ agonist, against lung IR injury. Parameters of lung injury, dysfunction and inflammation showed a significant dose-dependent improvement after exogenous $A_{1} R$ activation. These results are in agreement with other reports of improved lung function after $A_{1} R$ activation in acute lung injury models. 5,21 
In addition to defining a protective role of exogenous $A_{1} R$ activation in lung IR injury, our results provide insight into potential mechanisms for $A_{1} R$-mediated anti-inflammatory effects. One mechanism of lung protection by $\mathrm{A}_{1} \mathrm{R}$ agonist is the modulation of cytokines and chemokines, which are important for the recruitment and activation of effector cells such as neutrophils. In the present study, CCPA attenuated the levels of several proinflammatory cytokines/chemokines after IR, including IL-6, CXCL1 (KC), CCL2 (MCP-1) and TNF-a. This suggests that activation of $A_{1}$ Rs on cells such as alveolar epithelial cells or macrophages could directly affect the secretion of CCL2 and TNF- $a$, respectively, by these cells and that an $\mathrm{A}_{1} \mathrm{R}$ agonist, such as CCPA, can exogenously activate $\mathrm{A}_{1} \mathrm{R}$-mediated antiinflammatory effects. The elevation in CXCL1, CCL2 and TNF- $a$ in $A_{1} R-/-$ mice after IR has also been described in a model of kidney IR injury, in which reconstitution of $A_{1} R$ via lentivirus injection encoding for the human $A_{1} R$ gene decreased CCL2 and TNF- $a$ expression to sham levels. ${ }^{22}$

Another potential mechanism of $\mathrm{A}_{1} \mathrm{R}$ agonist-mediated protection is the modulation of inflammatory cell recruitment. Studies have shown that activation and migration of neutrophils are crucial events that modulate the inflammation process after IR, and the important role of neutrophil recruitment in lung IR injury has been demonstrated in our laboratory. ${ }^{23}$ The current study showed that WT mice had significantly elevated MPO levels in BAL fluid after IR, and that $\mathrm{A}_{1} \mathrm{R}$ activation via CCPA reduced MPO levels, indicating a reduction in alveolar neutrophil activation and recruitment. These results are in agreement with prior studies in lung ${ }^{5}$ and kidney IR models. ${ }^{16}$

In vitro studies have shown that $\mathrm{A}_{1} \mathrm{R}$ agonist decreases albumin permeability across confluent bovine pulmonary artery endothelial cell monolayers. ${ }^{24}$ Our present study evaluated the direct effect of selective $\mathrm{A}_{1} \mathrm{R}$ activation on neutrophil chemotaxis in vitro. Bone marrow-derived neutrophils incubated with 10\% FBS demonstrated increased chemotaxis compared to cells incubated with medium alone, and CCPA treatment significantly attenuated neutrophil chemotaxis. These results demonstrate that $\mathrm{A}_{1} \mathrm{R}$ agonist can act directly on neutrophils to impair migration.

Although we anticipated that the $A_{1} R-/-$ mice would have worse lung IR injury compared to WT mice, these mice displayed a level of injury similar to WT mice. These results could have several explanations. First, one explanation might lie with the fact that endogenous adenosine production during IR can act on any or all of the four adenosine receptors to initiate signalling pathways that can have synergistic or antagonistic effects. The pharmacology of adenosine receptor signalling is complex, and the role of these individual receptors can be pro-inflammatory or anti-inflammatory during lung IR injury as noted above. Hence, in $\mathrm{A}_{1} \mathrm{R}-/-$ mice, endogenous adenosine could still exert an anti-inflammatory effect via other adenosine receptors such as $A_{3} R$ or $A_{2 A} R$, thereby preventing worse lung injury after IR. Second, adenosine receptor signalling cascades that occur in $A_{1} R-/-$ mice remain unknown and could be disrupted, and it is possible that potential crosstalk between $A_{1} R$ and other adenosine receptors could be altered in $A_{1} R-/-$ mice. Several studies now point to synergistic mechanisms between various adenosine receptors, especially $A_{1} R$, $\mathrm{A}_{2 \mathrm{~A}} \mathrm{R}$ and $\mathrm{A}_{2 \mathrm{~B}} \mathrm{R}$. For example, Urmaliya et al. found that endogenous adenosine contributes to $\mathrm{A}_{1} \mathrm{R}$-mediated cardioprotection by cooperative interactions with both $\mathrm{A}_{2 \mathrm{~A}} \mathrm{R}$ and $\mathrm{A}_{2 \mathrm{~B}} \mathrm{R}{ }^{25,} 26$ The complex and cooperative adenosine receptor signalling mechanisms involved in lung IR injury remain unknown, and it is likely that similar cooperative pathways are disrupted in the $\mathrm{A}_{1} \mathrm{R}-/-$ mice. Importantly, however, the exogenous activation of $\mathrm{A}_{1} \mathrm{R}$ by CCPA in WT mice in the present study clearly resulted in significant protection from lung injury and dysfunction after IR, thereby supporting therapeutic use of $A_{1} R$ agonists to prevent lung IR injury. 
In conclusion, we have demonstrated the protective, anti-inflammatory effects of an $\mathrm{A}_{1} \mathrm{R}$ agonist in the setting of lung IR injury. Exogenous $A_{1} R$ activation via CCPA improved lung function, injury and inflammation after IR. These protective effects involved the attenuation of edema, pro-inflammatory cytokines, and infiltration and chemotaxis of neutrophils. These results suggest that the pharmacological activation of $A_{1} R$ via selective agonists could be a promising strategy to prevent and/or treat lung IR injury and primary graft dysfunction after transplantation.

\section{Acknowledgments}

This study was funded by NIH, NHLBI grant \# R01HL092953 (ILK/VEL)

\section{References}

1. den Hengst WA, Gielis JF, Lin JY, Van Schil PE, De Windt LJ, Moens AL. Lung ischemiareperfusion injury: a molecular and clinical view on a complex pathophysiological process. Am J Physiol Heart Circ Physiol. 2010; 299:H1283-99. [PubMed: 20833966]

2. Laubach VE, Kron IL. Pulmonary inflammation after lung transplantation. Surgery. 2009; 146:1-4. [PubMed: 19541003]

3. Fan M, Qin W, Mustafa SJ. Characterization of adenosine receptor(s) involved in adenosineinduced bronchoconstriction in an allergic mouse model. Am J Physiol Lung Cell Mol Physiol. 2003; 284:L1012-9. [PubMed: 12533441]

4. Salvatore CA, Jacobson MA, Taylor HE, Linden J, Johnson RG. Molecular cloning and characterization of the human A3 adenosine receptor. Proc Natl Acad Sci U S A. 1993; 90:10365-9. [PubMed: 8234299]

5. Gazoni LM, Walters DM, Unger EB, Linden J, Kron IL, Laubach VE. Activation of A1, A2A, or A3 adenosine receptors attenuates lung ischemia-reperfusion injury. J Thorac Cardiovasc Surg. 2010; 140:440-6. [PubMed: 20398911]

6. Sharma AK, Laubach VE, Ramos SI, Zhao Y, Stukenborg G, Linden J, et al. Adenosine A2A receptor activation on $\mathrm{CD} 4+\mathrm{T}$ lymphocytes and neutrophils attenuates lung ischemia-reperfusion injury. J Thorac Cardiovasc Surg. 2009; 139:474-82. [PubMed: 19909990]

7. LaPar DJ, Laubach VE, Emaminia A, Crosby IK, Hajzus VA, Sharma AK, et al. Pretreatment strategy with adenosine A2A receptor agonist attenuates reperfusion injury in a preclinical porcine lung transplantation model. J Thorac Cardiovasc Surg. 2011; 142:887-94. [PubMed: 21762933]

8. Anvari F, Sharma AK, Fernandez LG, Hranjec T, Ravid K, Kron IL, et al. Tissue-derived proinflammatory effect of adenosine A2B receptor in lung ischemia-reperfusion injury. J Thorac Cardiovasc Surg. 2010; 140:871-7. [PubMed: 20659747]

9. Fredholm BB, AP IJ, Jacobson KA, Klotz KN, Linden J. International Union of Pharmacology. XXV. Nomenclature and classification of adenosine receptors. Pharmacol Rev. 2001; 53:527-52. [PubMed: 11734617]

10. Neely CF, Keith IM. A1 adenosine receptor antagonists block ischemia-reperfusion injury of the lung. Am J Physiol. 1995; 268:L1036-46. [PubMed: 7611426]

11. Ngamsri KC, Wagner R, Vollmer I, Stark S, Reutershan J. Adenosine receptor A1 regulates polymorphonuclear cell trafficking and microvascular permeability in lipopolysaccharide-induced lung injury. J Immunol. 2010; 185:4374-84. [PubMed: 20729330]

12. Sun CX, Young HW, Molina JG, Volmer JB, Schnermann J, Blackburn MR. A protective role for the A1 adenosine receptor in adenosine-dependent pulmonary injury. J Clin Invest. 2005; 115:3543. [PubMed: 15630442]

13. Sun D, Samuelson LC, Yang T, Huang Y, Paliege A, Saunders T, et al. Mediation of tubuloglomerular feedback by adenosine: evidence from mice lacking adenosine 1 receptors. Proc Natl Acad Sci U S A. 2001; 98:9983-8. [PubMed: 11504952]

14. Lohse MJ, Klotz KN, Schwabe U, Cristalli G, Vittori S, Grifantini M. 2-Chloro-N6cyclopentyladenosine: a highly selective agonist at A1 adenosine receptors. Naunyn Schmiedebergs Arch Pharmacol. 1988; 337:687-9. [PubMed: 3216901] 
15. Kim J, Kim M, Song JH, Lee HT. Endogenous A1 adenosine receptors protect against hepatic ischemia reperfusion injury in mice. Liver Transpl. 2008; 14:845-54. [PubMed: 18324658]

16. Lee HT, Gallos G, Nasr SH, Emala CW. A1 adenosine receptor activation inhibits inflammation, necrosis, and apoptosis after renal ischemia-reperfusion injury in mice. J Am Soc Nephrol. 2004; 15:102-11. [PubMed: 14694162]

17. Tsuchida A, Liu GS, Wilborn WH, Downey JM. Pretreatment with the adenosine A1 selective agonist, 2-chloro-N6-cyclopentyladenosine (CCPA), causes a sustained limitation of infarct size in rabbits. Cardiovasc Res. 1993; 27:652-6. [PubMed: 8324800]

18. Ozacmak VH, Sayan H. Pretreatment with adenosine and adenosine A1 receptor agonist protects against intestinal ischemia-reperfusion injury in rat. World J Gastroenterol. 2007; 13:538-47. [PubMed: 17278219]

19. Zheng J, Wang R, Zambraski E, Wu D, Jacobson KA, Liang BT. Protective roles of adenosine A1, $\mathrm{A} 2 \mathrm{~A}$, and $\mathrm{A} 3$ receptors in skeletal muscle ischemia and reperfusion injury. Am J Physiol Heart Circ Physiol. 2007; 293:H3685-91. [PubMed: 17921328]

20. Neely CF, DiPierro FV, Kong M, Greelish JP, Gardner TJ. A1 adenosine receptor antagonists block ischemia-reperfusion injury of the heart. Circulation. 1996; 94:II376-80. [PubMed: 8901778]

21. Heller AR, Rothermel J, Weigand MA, Plaschke K, Schmeck J, Wendel M, et al. Adenosine A1 and $\mathrm{A} 2$ receptor agonists reduce endotoxin-induced cellular energy depletion and oedema formation in the lung. Eur J Anaesthesiol. 2007; 24:258-66. [PubMed: 17094869]

22. Kim M, Chen SW, Park SW, D'Agati VD, Yang J, Lee HT. Kidney-specific reconstitution of the A1 adenosine receptor in A1 adenosine receptor knockout mice reduces renal ischemiareperfusion injury. Kidney Int. 2009; 75:809-23. [PubMed: 19190680]

23. Zhao Y, Sharma AK, LaPar DJ, Kron IL, Ailawadi G, Liu Y, et al. Depletion of tissue plasminogen activator attenuates lung ischemia-reperfusion injury via inhibition of neutrophil extravasation. Am J Physiol Lung Cell Mol Physiol. 2011; 300:L718-29. [PubMed: 21378024]

24. Paty PS, Sherman PF, Shepard JM, Malik AB, Kaplan JE. Role of adenosine in platelet-mediated reduction in pulmonary vascular permeability. Am J Physiol. 1992; 262:H771-7. [PubMed: 1558187]

25. Urmaliya VB, Church JE, Coupar IM, Rose'Meyer RB, Pouton CW, White PJ. Cardioprotection induced by adenosine $\mathrm{A} 1$ receptor agonists in a cardiac cell ischemia model involves cooperative activation of adenosine A2A and A2B receptors by endogenous adenosine. Journal of cardiovascular pharmacology. 2009; 53:424-33. [PubMed: 19333129]

26. Urmaliya VB, Pouton CW, Ledent C, Short JL, White PJ. Cooperative cardioprotection through adenosine $\mathrm{A} 1$ and $\mathrm{A} 2 \mathrm{~A}$ receptor agonism in ischemia-reperfused isolated mouse heart. Journal of cardiovascular pharmacology. 2010; 56:379-88. [PubMed: 20930592] 

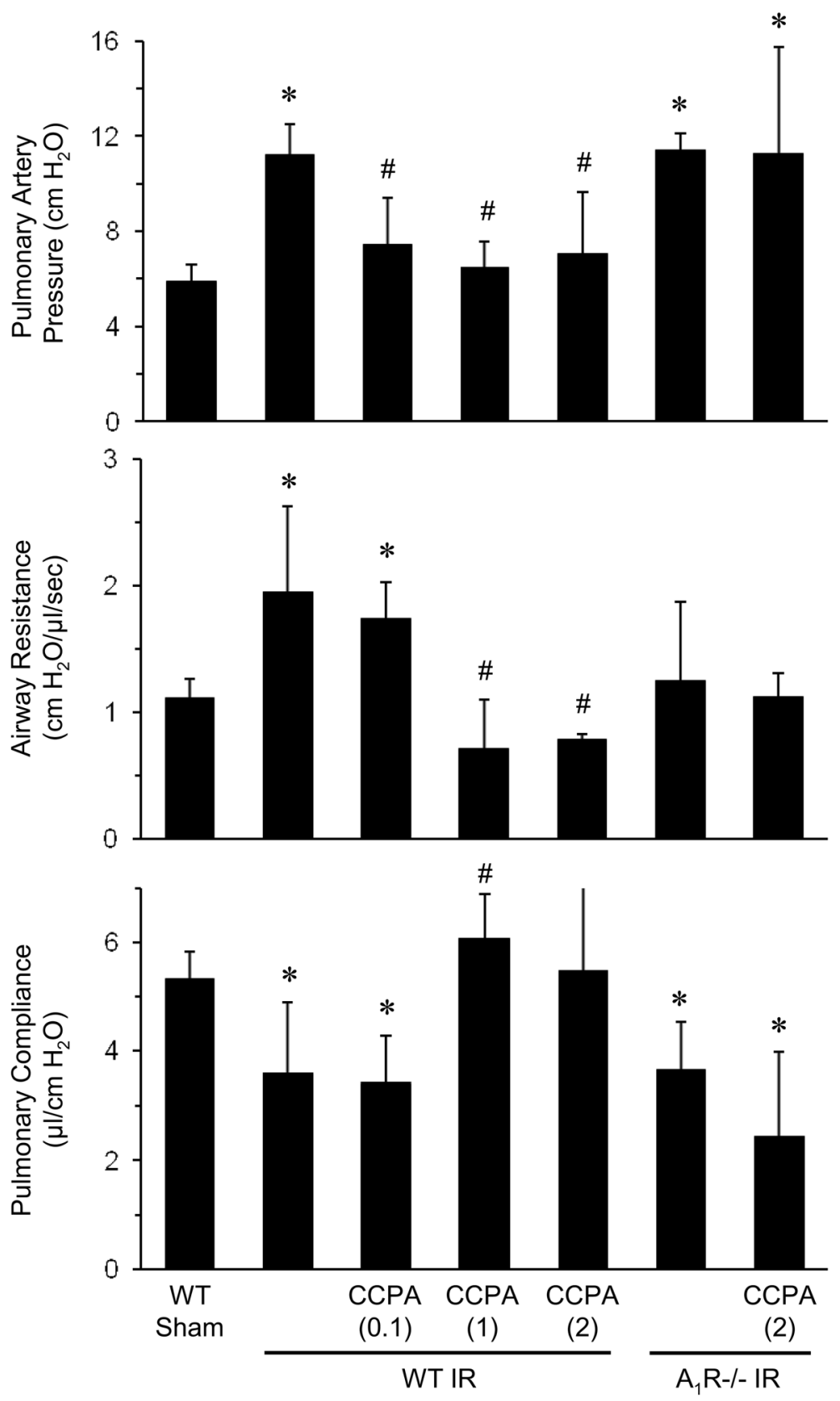

Figure 1. Lung function after IR is significantly improved by CCPA

WT and $A_{1} \mathrm{R}-/-$ mice were treated with vehicle or CCPA (doses in $\mathrm{mg} / \mathrm{kg}$ are shown in parentheses) prior to ischemia. In WT mice after IR, CCPA significantly decreased pulmonary artery pressure and airway resistance and increased pulmonary compliance. Lung function in $\mathrm{A}_{1} \mathrm{R}-/-$ mice after IR was not significantly different from WT mice after IR, and CCPA did not significantly affect lung function in $A_{1} R-/-$ mice. Lung function was similar between $\mathrm{WT}$ and $\mathrm{A}_{1} \mathrm{R}-/-$ mice after sham surgery (data not shown). $* P<0.03$ vs. WT sham, ${ }^{\#} P<0.03$ vs. WT IR. Means \pm SD are shown. 


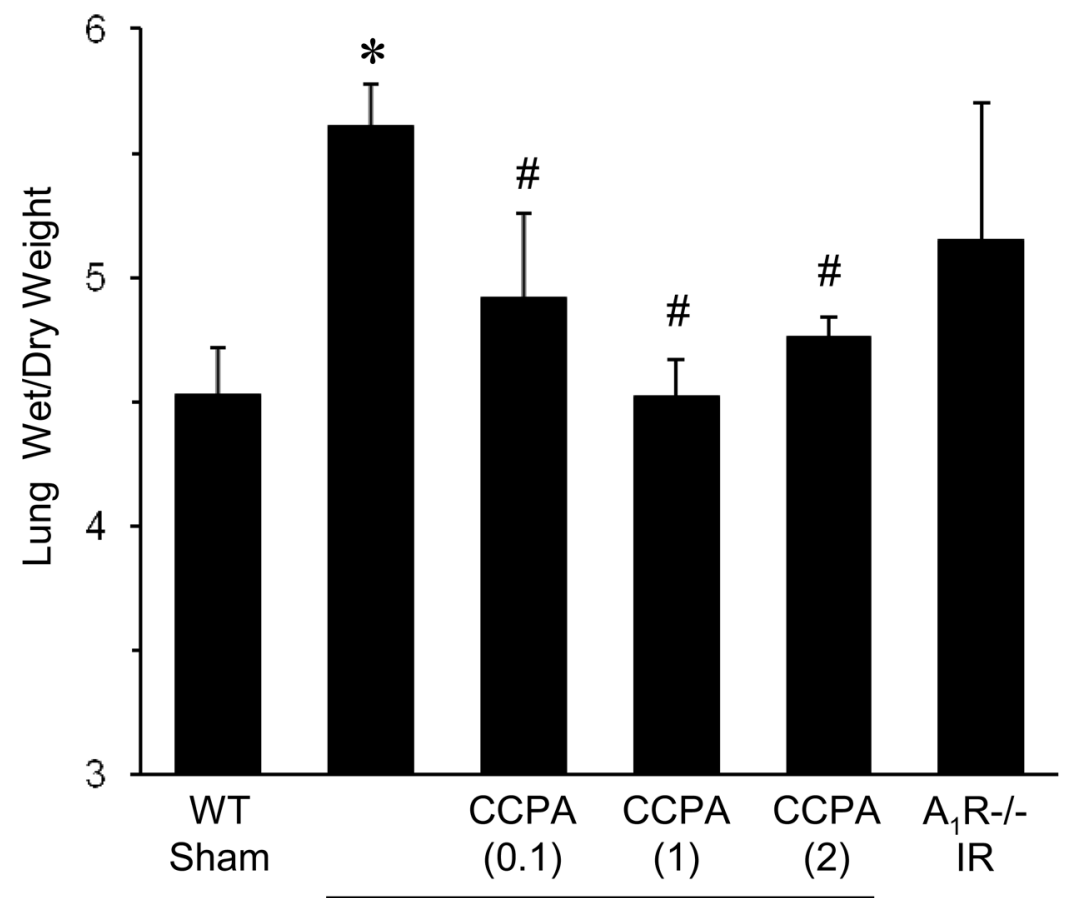

\section{WT IR}

Figure 2. Pulmonary edema after IR is significantly reduced by CCPA

Lung wet/dry weight ratio was measured after IR or sham surgery in $\mathrm{A}_{1} \mathrm{R}-\mathrm{l}-$ mice and in WT mice treated with vehicle or CCPA (doses in $\mathrm{mg} / \mathrm{kg}$ are shown in parentheses) prior to ischemia. Lung wet/dry weight was significantly increased after IR in WT mice, which was significantly attenuated by CCPA treatment. Lung wet/dry weight after IR was also elevated in $\mathrm{A}_{1} \mathrm{R}-/-$ mice after IR similar to WT mice after IR. Lung wet/dry weight was similar between WT and $\mathrm{A}_{1} \mathrm{R}-/-$ mice after sham surgery (data not shown). $* P<0.05$ vs. WT sham, ${ }^{\#} P<0.05$ vs. WT IR. Means \pm SD are shown. 

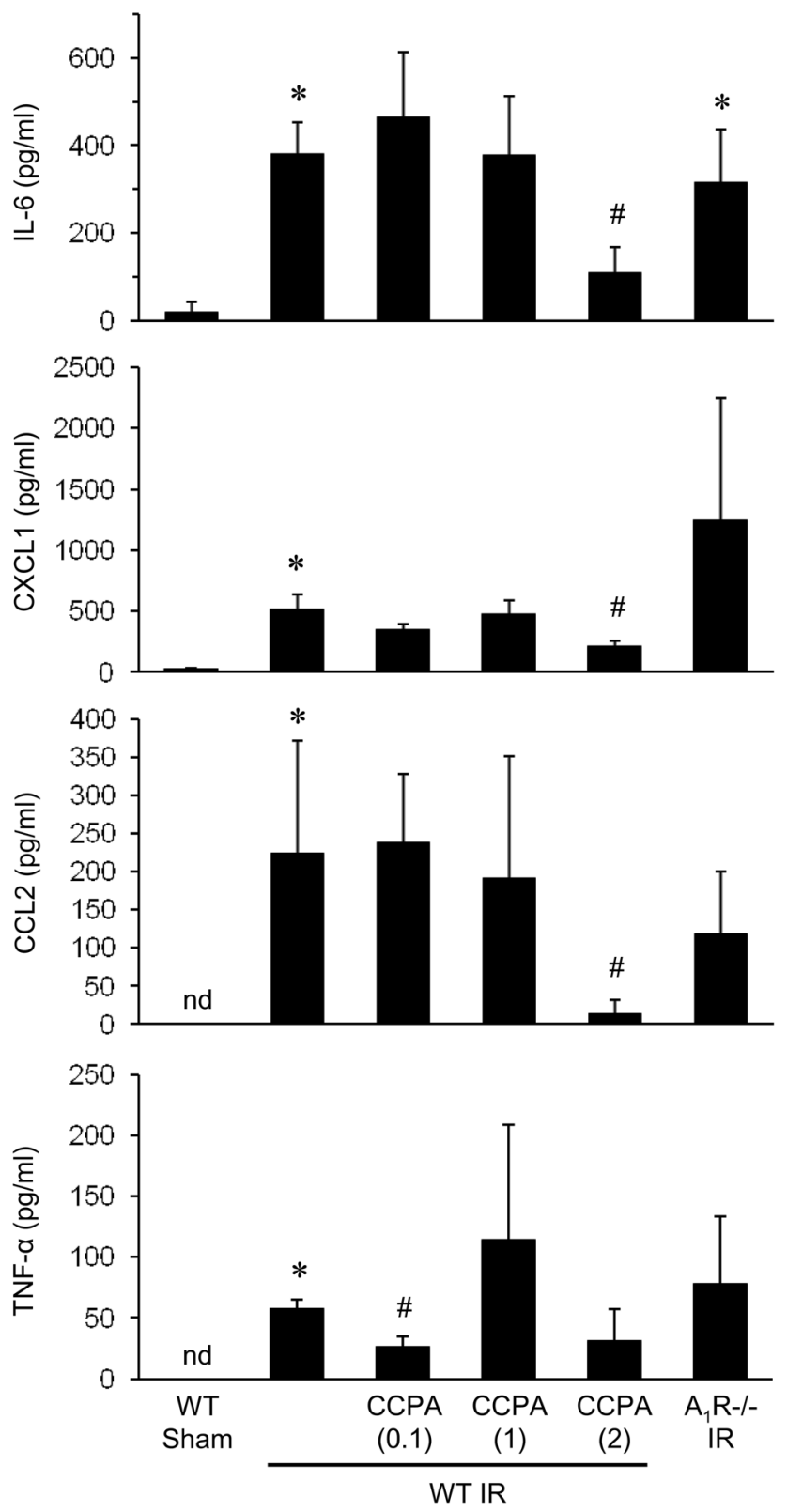

Figure 3. Expression of pro-inflammatory cytokines after IR is attenuated by CCPA

Cytokine levels in BAL fluid after IR or sham surgery were measured in $\mathrm{A}_{1} \mathrm{R}-/-$ mice and in WT mice treated with vehicle or CCPA (doses in $\mathrm{mg} / \mathrm{kg}$ are shown in parentheses) prior to ischemia. Expression of IL-6, CXCL1, CCL2 and TNF-a were all significantly increased after IR in WT mice, and CCPA treatment significantly attenuated cytokine levels after IR. Cytokine levels after IR were elevated in $\mathrm{A}_{1} \mathrm{R}-1-$ mice after IR similar to WT mice after IR. $* P<0.05$ vs. WT sham, ${ }^{\#} P<0.05$ vs. WT IR. nd $=$ not detectable. Means \pm SD are shown. 


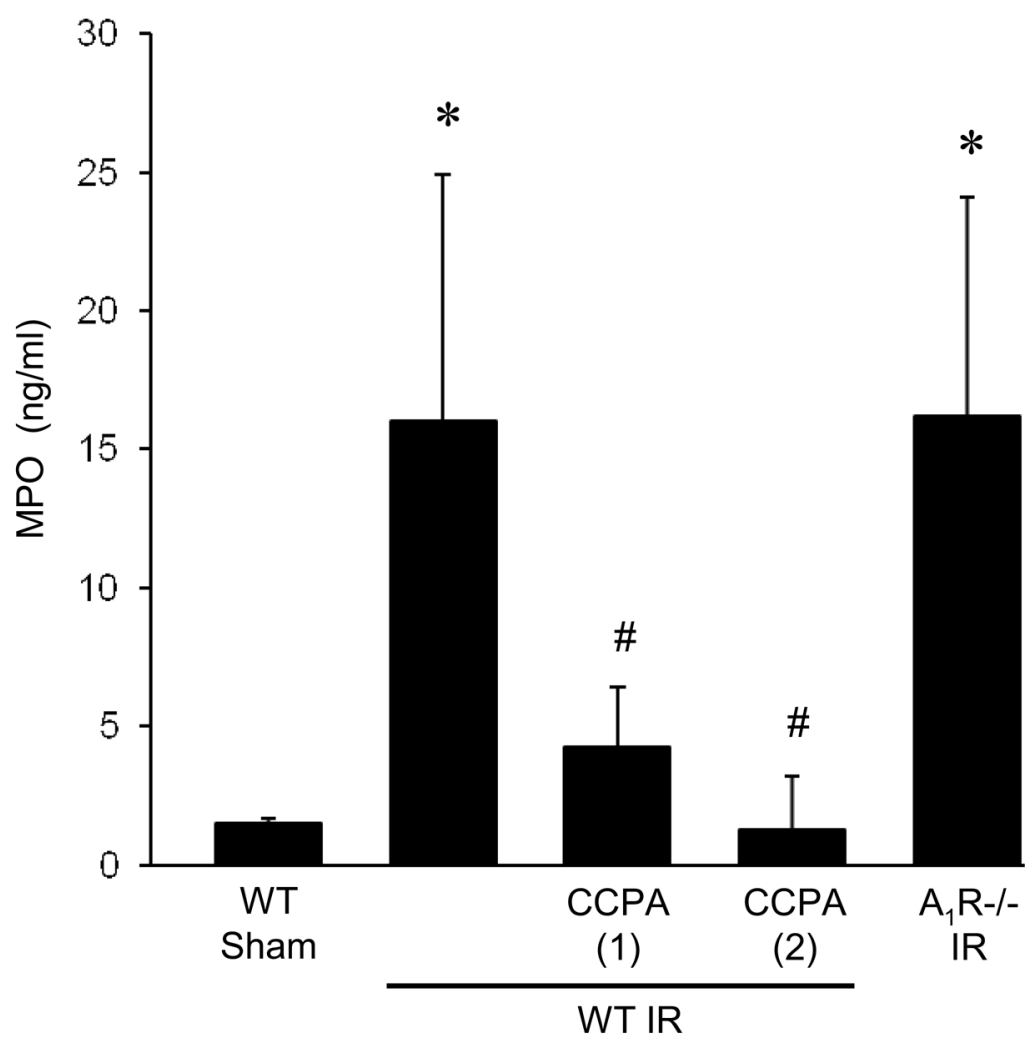

Figure 4. Myeloperoxidase (MPO) levels after IR are significantly reduced by CCPA MPO levels in BAL fluid, as an estimate of neutrophil infiltration into alveolar airspaces, after IR or sham surgery were measured in $\mathrm{A}_{1} \mathrm{R}-1-$ mice and in WT mice treated with vehicle or CCPA (doses in $\mathrm{mg} / \mathrm{kg}$ are shown in parentheses) prior to ischemia. Elevated MPO in WT mice after IR was significantly attenuated by CCPA. MPO levels were also elevated in $\mathrm{A}_{1} \mathrm{R}-1-$ mice after IR similar to WT mice after IR. ${ }^{*} P<0.05$ vs. WT sham, ${ }^{\#} P<$ 0.05 vs. WT IR. Means \pm SD are shown. 


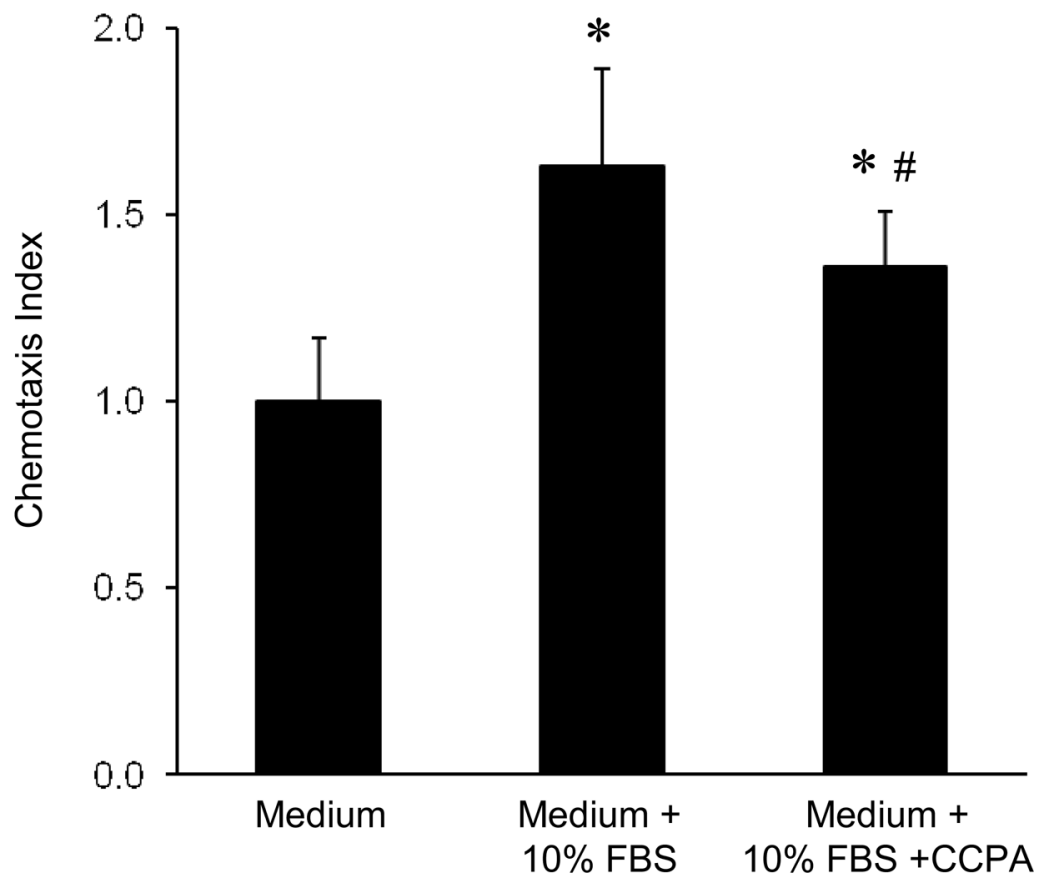

Figure 5. Neutrophil chemotaxis is significantly reduced by CCPA

Chemotaxis was measured in murine bone marrow-derived neutrophils as described in the methods. Chemotaxis was significantly increased in medium containing $10 \% \mathrm{FBS}$, which was significantly reduced by $10 \mathrm{ng} / \mathrm{ml} \mathrm{CCPA}$. ${ }^{*} P<0.001$ vs. medium, ${ }^{\#} P=0.03$ vs. medium $+10 \%$ FBS. Means \pm SD are shown. 